\title{
Eksplorasi Kemampuan Pemecahan Masalah Siswa SMA dengan Model Discovery Learning pada Materi Fluida Statis
}

\author{
Linda Purnamasari ${ }^{1 *}$, Abdul Hakim ${ }^{2}$, Nurul Fitriyah Sulaeman ${ }^{3}$, Darmadianingsih ${ }^{4}$ \\ $1^{*}, 2,3$ Program Studi Pendidikan Fisika, FKIP \\ Universitas Mulawarman, Samarinda - Indonesia \\ ${ }^{4}$ SMA Negeri 3 Samarinda \\ JI. Ir. H. Juanda 20, Samarinda, Kalimantan Timur, Indonesia \\ *E-mail Penulis Korespondensi: Ipurnamasaririi@gmail.com
}

\begin{abstract}
Abstrak
Penelitian ini bertujuan untuk mengeksplorasi kemampuan pemecahan masalah siswa pada materi fluida statis. Jenis penelitian yang digunakan adalah eksperimental kuasi, dengan desain penelitian yaitu tipe rancangan pasangan subjek melalui tes awal dan tes akhir dengan kelompok kontrol. Penelitian ini dilaksanakan di SMA Negeri 3 Samarinda. Pengambilan data menggunakan teknik tes yang dilaksanakan sebelum kegiatan pembelajaran (pretest) dan sesudah kegiatan pembelajaran (posttest), dengan jenis instrumen tes yaitu tes esai. Hasil analisis uji Mann-Whitney menunjukkan bahwa model discovery learning berpengaruh terhadap kemampuan pemecahan masalah siswa. Terjadi peningkatan kemampuan pemecahan masalah siswa baik kelas eksperimen maupun kelas kontrol. Hal ini didasarkan pada hasil uji $\mathrm{N}$-Gain dimana rata-rata $\mathrm{N}$-Gain kelas ekperimen adalah 0,6 dan kelas kontrol 0,3 yang mana keduanya termasuk kategori sedang. Sehingga dapat disimpulkan bahwa penerapan model discovery learning dapat meningkatkan kemampuan pemecahan masalah siswa SMA pada materi fluida statis.
\end{abstract}

Kata kunci: Kemampuan Pemecahan Masalah, Model Discovery Learning.

\section{Abstract}

This study aims to explore problem solving skills in static fluid materials. The type of research used is quasi experimental, with research design is The Matching Only Pretest-Posttest Control Group Design. This research was conducted at SMA Negeri 3 Samarinda. Data collection using test techniques carried out before and after learning activities, with the type of test instruments that are essay tests. The results of the Mann-Whitney test analysis showed that the discovery learning model influenced students' problem-solving abilities. There was an increase in students' problem-solving skills in experimental and control classes. Based on the N-Gain test results where the average $\mathrm{N}$-Gain of the experiment class is 0.6 and the control class is 0.3 where both belong to the medium category. So, it can be concluded that the application of the discovery learning model can improve the problem solving skills of high school students on static fluid.

Keywords: Problem Solving Skills, Discovery Learning.

Article History: Received: 12 Maret 2021

Accepted: 19 Maret 2021

\section{Revised : 22 Maret 2021}

Published: 30 April 2021

How to cite: Purnamasari, L., Hakim, A., Sulaeman, N.F., \& Dharmadianingsih. (2021). Eksplorasi Kemampuan Pemecahan Masalah Siswa SMA dengan Model Discovery Learning pada Materi Fluida Statis, Jurnal Literasi Pendidikan Fisika, 2 (1). pp. 9-22. Retrieved from http://jurnal.fkip.unmul.ac.id/index.php/JLPF

Copyright @ April 2021, Jurnal Literasi Pendidikan Fisika 
Eksplorasi Kemampuan Pemecahan...

\section{PENDAHULUAN}

Mutu pendidikan Indonesia yang rendah telah banyak disadari oleh berbagai pihak, terutama oleh para ahli dan pemerhati pendidikan. Dalam Kemendikbud (2019) mengenai laporan studi Programme for International Student Assessment (PISA) tahun 2018, menunjukkan bahwa kemampuan siswa Indonesia dalam membaca meraih skor rata-rata yakni 371 dengan rata-rata skor OECD yakni 487. Kemudian untuk skor rata-rata matematika mencapai 379 dengan skor rata-rata OECD 487. Selanjutnya untuk sains, skor rata-rata siswa Indonesia mencapai 389 dengan skor rata-rata OECD yakni 489. Dalam bidang MIPA, survei hasil studi Trends in International Mathematics and Science Study (TIMSS) tahun 2015, Indonesia berada di peringkat 45 dari 50 negara, dengan pencapaian skor 397 dan masih dibawah skor rata-rata internasional, yaitu 500. Hal ini mengindikasikan kemampuan fisika siswa harus ditingkatkan pada semua aspek, khususnya aspek reasoning (Masjaya, 2018).

Pembelajaran fisika adalah pembelajaran yang tidak mengabaikan hakihat fisika sebagai sains. Hakikat sains yang dimaksud meliputi produk, proses, dan sikap ilmiah. Pembelajaran fisika seharusnya bisa memberikan pengalaman langsung pada siswa sehingga menambah kemampuan dalam mengkonstruksi, memahami, dan menerapkan konsep yang telah dipelajari. Dengan demikian, siswa akan terlatih menemukan sendiri berbagai konsep secara holistik, bermakna, otentik serta aplikatif untuk kepentingan pemecahan masalah (Taufik, 2010).

Menurut Sulistyowati (2013) model pembelajaran Discovery Learning berasal dari kata "Discovery" yang artinya "penemuan", yaitu pembelajaran yang melibatkan proses mental yang terjadi dalam diri perserta didik. Proses mental yang terjadi adalah observasi, klasifikasi, pengukuran, prediksi, penentuan, dan lain-lain. Penemuan (Discovery) merupakan suatu model pembelajaran yang dikembangkan berdasarkan pandangan kontruktivisme. Model ini menekankan pentingnya pemahaman struktur atau ide-ide penting terhadap suatu disiplin ilmu, melalui keterlibatan siswa secara aktif dalam proses pembelajaran (Slavin, 1997). Menurut Wilcox (dalam Slavin, 1997), dalam pembelajaran dengan penemuan, siswa didorong untuk belajar melalui keterlibatan aktif mereka sendiri dengan konsep-konsep dan prinsip-prinsip, dan guru mendorong siswa untuk memiliki pengalaman dan melakukan percobaan yang memungkinkan mereka untuk menemukan prinsip-prinsip untuk diri mereka sendiri. Menurut Suprijono (2012), Model Discovery Learning merupakan pembelajaran yang beraksentuasi pada masalah-masalah kontekstual dan menekankan pada aktivitas penyelidikan. Kurniawati (2011) mengatakan bahwa penerapan Discovery Learning dapat meningkatkan keterampilan siswa. Keterampilan yang dimiliki siswa mengalami peningkatan dalam kegiatan praktikum dan pengerjaaan latihan soal berupa soal esai. Dari beberapa pengertian model pembelajaran Discovery Learning di atas, maka dapat disimpulkan bahwa model pembelajaran Discovery Learning adalah suatu model pembelajaran yang melibatkan proses mental, dimana siswa terlibat aktif dan guru mendorong atau membimbing siswa untuk menemukan prinsip-prinsip, memahami konsep, arti dan hubungan melalui proses, baik dengan melakukan percobaan atau penyelidikan untuk akhirnya sampai pada suatu kesimpulan.

Pemecahan masalah oleh Evans (dalam Fadhlin, 2012) didefinisikan sebagai suatu aktivitas yang berhubungan dengan pemilihan jalan keluar atau cara yang cocok bagi tindakan dan pengubahan kondisi sekarang (present state) menuju kepada situasi yang diharapkan (future state atau desire goal). Keterampilan memecahan masalah dapat diajarkan. Pemecahan masalah data dipandang sebagai manipulasi informasi secara sistematis, langkah demi langkah dengan mengolah informasi yang diperoleh melalui pengamatan untuk mencapai suatu hasil pemikiran sebagai respon terhadap problema yang dihadapi. Untuk memecahkan masalah kita harus melokasi informasi, menampilkannya dari ingatan lalu memprosesnya dengan maksud untuk mencari hubungan, pola, atau pilihan baru. Keterampilan memecahkan masalah adalah terampil dalam mengambil keputusan secara rasional (Fadhlin, 2014). Suharsono (dalam Destianingsih, 2015) mengatakan bahwa para ahli pembelajaran sependapat bahwa kemampuan pemecahan dalam batas-batas tertentu dapat dibentuk melalui bidang studi dan disiplin ilmu yang diajarkan. Menurut Daeka (dalam Yunita Herdiana, 2017) rendahnya

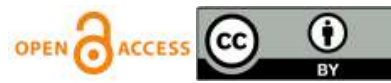


Eksplorasi Kemampuan Pemecahan...

kemampuan pemecahan masalah siswa, salah satunya karena siswa kurang melatih kemampuannya dalam pemecahan masalah. Siswa terbiasa menghapal definisi, teorema, dan rumus-rumus. Banyak alternatif yang dapat dilakukan agar penyajian materi pembelajaran lebih menarik, sehingga pembelajaran yang dilakukan dapat meningkatkan kemampuan pemecahan masalah. Berdasarkan pendapat para ahli tersebut, maka dapat disimpulkan bahwa penyelesaian masalah merupakan kemampuan menggunakan pengetahuan dan keterampilan yang dimiliki untuk mendapatkan solusi dari masalah yang dihadapi, dengan mengenali karakteristik masalah, menghubungkan pengamatan, pengalaman, dan informasi-informasi yang telah diperoleh serta membiasakan diri untuk melatih kemampuan pemecahan masalah.

Polya (dalam Bekti, 2014) mendefinisikan pemecahan masalah sebagai suatu usaha mencari jalan keluar dari suatu tujuan yang tidak mudah dicapai dengan menetapkan empat tahap yang dapat dilakukan agar siswa lebih terarah dalam menyelesaikan masalah, yaitu understanding the problem, devising plan, carrying out the plan, and looking back, yang diartikan sebagai memahami masalah, menyusun rencana pemecahan masalah, melaksanakan rencana, dan memeriksa kembali hasil yang diperoleh. Adanya tahapan-tahapan tersebut agar memudahkan seorang guru untuk menilai bagaimana kemampuan pemecahan masalah siswanya dalam menghadapi permasalah yang diberikan guru dalam pembelajaran. Pemecahan masalah merupakan salah satu bagian penting untuk menerapkan konsep-konsep fisika dalam pembelajaran fisika. Dwi (2012), mengungkapkan bahwa pemecahan masalah merupakan salah satu tolak ukur kualitas siswa di zaman modern ini. Selain itu, pemecahan masalah membantu siswa untuk mengkonstruksi pengetahuan baru, memfasilitasi pembelajaran fisika dan terlebih lagi dalam menyelesaikan soal-soal fisika dalam bertuk tes uraian yang dapat mengembangkan keterampilan pemecahan masalah.

Permasalahan yang banyak dihadapi siswa dalam memecahkan soal-soal tes fisika, diantaranya siswa tidak memiliki kemampuan menyelesaikan soal-soal secara sistematis, sulit mencerna pokok pertanyaan, tidak mudah menentukan besaran-besaran fisika dan simbol-simbol yang terdapat dalam pertanyaan. Siswa juga terkadang masih sulit menentukan konsep, prinsip, teori, hukum, dan rumus yang dipakai untuk memecahkan, menjawab atau menyelesaikan soal. Kemampuan pemecahan masalah pada pembelajaran fisika masih rendah karena proses pembelajaran belum berorientasi untuk mengembangkan kemampuan dalam pemecahan masalah. Salah satu penyebabnya adalah jarang menggunakan media atau eksperimen sebagai penunjang pembelajaran sehingga belum dapat memotivasi siswa untuk lebih tertarik belajar fisika. Permasalahan lain yang mempengaruhi yaitu model pembelajaran yang digunakan guru belum sesuai. Sehingga pada proses pembelajaran siswa terlihat pasif. Model pembelajaran yang tidak sesuai dapat menghambat kreativitas siswa dalam memecahkan masalah fisika.

Permasalahan diatas salah satunya dapat diatasi dengan mengambil alternatif tindakan melalui model Discovery Learning. Model Discovery Learning merupakan model pembelajaran yang dapat mengembangkan kreativitas siswa dalam pemecahan masalah. Sehingga melalui model Discovery Learning diharapkan dapat meningkatkan kreativitas siswa dalam pemecahan masalah. Berdasarkan permasalahan di atas, maka penulis melakukan penelitian tentang penerapan model pembelajaran Discovery Learning terhadap kemampuan pemecahan masalah fisika pada materi fluida statis kelas XI MIPA 4 dan XI MIPA 5 SMA Negeri 3 Samarinda.

\section{METODE}

Jenis penelitian yang digunakan merupakan jenis penelitian kuantitatif yang menerapkan eksperimental kuasi (quasi experimental research). Penelitian ini menggunakan desain penelitian dengan tipe rancangan pesangan subjek melalui tes awal (pretest) dan tes akhir (posttest) dengan kelompok kontrol (The Matching Only Pretest-Posttest Control Group Design) digambarkan oleh Freankel dan Wallen (2012), yang ditunjukkan pada Tabel 1. 
Eksplorasi Kemampuan Pemecahan...

Tabel 1. Desain Penelitian

\begin{tabular}{lcccc}
\hline Treatment Group & $M$ & $O$ & $X$ & $O$ \\
\hline Control Group & $M$ & $O$ & $C$ & $O$ \\
\hline$M=$ kelas eksperimen, $M=$ kelas kontrol, & $O=$ pengukuran \\
awal (pretest) dan pengukuran akhir & (posttest), $X=$ \\
perlakuan dengan penerapan model discovery learning, $C$ \\
$=$ perlakuan dengan penerapan model \\
konvensional
\end{tabular}

Penelitian ini dilaksanakan di SMA Negeri 3 Samarinda pada tanggal 2 sampai 16 Oktober 2019. Teknik pengambilan sampel dalam penelitian ini menggunakan purposive sampling, yaitu teknik penentuan sample dengan pertimbangan tertentu. Sehingga diperoleh kelas XI MIPA 4 dan XI MIPA 5 SMA Negeri 3 Samarinda sebagai sampel. Teknik pengumpulan data yang digunakan untuk mengetahui kemampuan pemecahan masalah siswa adalah teknik tes. Tes ini dilakukan di pertemuan awal pembelajaran (pretest) dan pertemuan terakhir pembelajaran (posttest), dengan jenis instrumen tes yaitu tes essai sebanyak 10 soal. Adapun teknik analisis data yang digunakan dalam menjawab rumusan masalah pada penelitian ini, yaitu:

1. Analisis Kemampuan Pemecahan Masalah

Kemampuan pemecahan masalah siswa pada penelitian ini menggunakan tahapan pemecahan masalah menurut Polya sehingga digunakan kriteria pensekoran tes kemampuan pemecahan masalah yang disajikan dalam Tabel 2.

Tabel 2. Kriteria Pensekoran Tes Kemampuan Pemecahan Masalah (Polya)

\begin{tabular}{|c|c|c|}
\hline $\begin{array}{l}\text { Aspek yang } \\
\text { dinilai }\end{array}$ & Keterangan & Skor \\
\hline \multirow{4}{*}{$\begin{array}{l}\text { Memahami } \\
\text { Masalah }\end{array}$} & Tidak memahami permasalahan (tidak ada jawaban) & 0 \\
\hline & Tidak tepat dalam memahami masalah (informasi yang ditulis tidak tepat) & 1 \\
\hline & Pemahaman masalah sebagian saja (informasi yang ditulis sebagian saja) & 2 \\
\hline & $\begin{array}{l}\text { Memahami masalah dengan tepat (menuliskan kembali semua informasi dalam } \\
\text { soal mengenai apa yang ditanyakan dengan tepat) }\end{array}$ & 3 \\
\hline \multirow{4}{*}{$\begin{array}{c}\text { Merencanakan } \\
\text { Pemecahan } \\
\text { Masalah }\end{array}$} & Tidak ada perencanaan pemecahan masalah (tidak ada strategi sama sekali) & 0 \\
\hline & $\begin{array}{l}\text { Perencanaan pemecahan masalah tidak tepat (menggunakan strategi yang tidak } \\
\text { relevan dan tidak dapat dijalankan) }\end{array}$ & 1 \\
\hline & $\begin{array}{l}\text { Perencanaan pemecahan masalah sebagian saja (menggunakan strategi yang } \\
\text { benar tetapi mengarah pada jawaban yang salah) }\end{array}$ & 2 \\
\hline & $\begin{array}{l}\text { Perencanaan pemecahan masalah yang tepat (menggunakan strategi yang benar } \\
\text { dan mengarah pada jawaban yang benar) }\end{array}$ & 3 \\
\hline \multirow{4}{*}{$\begin{array}{c}\text { Melaksanakan } \\
\text { Rencana } \\
\text { Pemecahan }\end{array}$} & Tidak menjawab pertanyaan & 0 \\
\hline & Menjawab pertanyaan namun kurang tepat (salah) & 1 \\
\hline & Menjawab pertanyaan dengan tepat namun kurang lengkap & 2 \\
\hline & Menjawab pertanyaan dengan tepat dan lengkap & 3 \\
\hline \multirow{4}{*}{$\begin{array}{l}\text { Mengecek } \\
\text { Kembali }\end{array}$} & Tidak ada respon (tidak ada pemeriksaan kembali/tidak ada keterangan) & 0 \\
\hline & Respon tidak tepat (ada pemeriksaan kembali tetapi tidak tepat) & 1 \\
\hline & Pelaporan yang memadai (ada pemeriksaan kembali tetapi tidak tuntas) & 2 \\
\hline & $\begin{array}{l}\text { Pelaporan secara tepat (pemeriksaan dilakukan untuk melihat kebenaran } \\
\text { hasil/keterangan tepat) }\end{array}$ & 3 \\
\hline
\end{tabular}

(Selcukk dkk, 2008)

\section{Analisis Normalized Gain (N-Gain)}

Uji Normalized Gain ( $N$-Gain) merupakan sebuah uji yang bisa memberikan gambaran umum peningkatan skor hasil pembelajaran antara sebelum dan sesudah diterapkannya suatu metode. Ratarata kemampuan pemecahan masalah siswa akan dilihat peningkatannya menggunakan SPSS 24 for Windows. Adapun kriteria perolehan nilai $\mathrm{N}$-Gain disajikan pada Tabel 3. 
Eksplorasi Kemampuan Pemecahan...

Tabel 3. Kriteria Perolehan N-Gain

\begin{tabular}{cc}
\hline Nilai $\mathbf{N}$-Gain & Kriteria \\
\hline$N$-Gain $>0,7$ & Tinggi \\
\hline $0,3 \leq N$-Gain $\leq 0,7$ & Sedang \\
\hline$N$-Gain $<0,3$ & Rendah \\
\hline & Sumber: Hake, 1999
\end{tabular}

\section{Analisis Kesamaan Dua Rerata}

Analisis kesamaan dua rerata bertujuan untuk mengetahui ada tidaknya perbedaan atau kesamaan antara nilai rata-rata kemampuan pemecahan masalah siswa sebelum diberi perlakuan dan setelah diberikan perlakuan. Analisis ini dilakukan dengan uji-t berpasangan. Sebelum dilakukan uji-t, terlebih dahulu dilakukan uji normalitas dan homogenitas.

a. Uji Normalitas

Uji normalitas bertujuan untuk mengetahui apakah sampel diambil dari populasi yang terdistribusi dengan normal. Uji normalitas yang digunakan adalah Kolmogorov-Smirnov karena sampel lebih dari 50. Perhitungan dilakukan dengan menggunakan software SPSS 24 for Windows. Distribusi normal baku adalah data yang telah ditransformasikan ke dalam bentuk $p$ dan diasumsikan normal. Jika nilainya di atas 0,05 maka distribusi dinyatakan memenuhi asumsi normalitas, dan jika nilainya di bawah 0,05 maka diinterpretasikan sebagai tidak normal.

b. Uji Homogenitas

Uji homogenitas bertujuan untuk mengetahui apakah dua data sampel yang diperoleh berasal dari populasi dengan variansi yang sama. Pengujian dilakukan menggunakan software SPSS 24 for Windows. Bila hasil perhitungan lebih besar dari taraf signifikan 0,05 maka data tersebut homogen, sebaliknya bila kurang dari 0,05 maka data tidak homogen.

\section{c. Uji-t Berpasangan}

Uji-t berpasangan digunakan untuk mengetahui ada tidaknya perbedaan perolehan kemampuan pemecahan masalah dari hasil pretest dan posttest setelah diajarkan dengan model discovery learning. Uji-t berpasangan dilakukan dengan menggunakan aplikasi SPSS 24 for Windows. Adapun hipotesis yang digunakan dalam penelitian ini adalah

$$
\begin{gathered}
H_{0}: \mu_{1}=\mu_{2} \\
H_{a}: \mu_{1} \neq \mu_{2}
\end{gathered}
$$

$\mathrm{H}_{\mathrm{o}}$ : tidak ada perbedaan yang signifikan antara kemampuan pemecahan masalah siswa kelas eksperimen dengan model pembelajaran discovery dan kelas kontrol dengan model pembelajaran konvensional

$\mathrm{H}_{\mathrm{a}}$ : ada perbedaan yang signifikan antara kemampuan pemecahan masalah siswa kelas eksperimen dengan model pembelajaran discovery dan kelas kontrol dengan model pembelajaran konvensional

$\mu_{1}$ : rata-rata skor hasil pretest

$\mu_{2}$ : rata-rata skor hasil posttest

Pengambilan keputusan pada uji-t berpasangan berdasarkan nilai signifikan dengan SPSS.

1) Jika nilai probabilitas (thitung $>$ tabel) maka terdapat pengaruh yang signifikan dari model discovery learning pada data pretest dan posttest terhadap kemampuan pemecahan masalah siswa atau probabilitas lebih kecil dari $5 \%(\mathrm{p}<0,05)$

2) Jika nilai probabilitas (thitung $<$ tabel) maka tidak terdapat pengaruh yang signifikan dari model discovery learning pada data pretest dan posttest terhadap kemampuan pemecahan masalah siswa. 
Eksplorasi Kemampuan Pemecahan...

\section{HASIL DAN PEMBAHASAN}

\section{HASIL}

Hasil penelitian dari pembelajaran fisika pada materi fluida statis ini digunakan untuk mengetahui bagaimana pengaruh model discovery learning terhadap kemampuan pemecahan masalah siswa, dimana sampel yang digunakan berjumlah 70 siswa yang terbagi dalam dua kelas yang masing-masing berjumlah 35 siswa yaitu kelas XI MIPA 4 sebagai kelas eksperimen dan kelas XI MIPA 5 sebagai kelas kontrol. Data hasil penelitian diperoleh dengan mengambil nilai pretest pada pertemuan pertama dan posttest yang dilakukan pada pertemuan terakhir dengan jumlah soal sebanyak 10 butir soal esai. Pada kelas eksperimen terdapat 4 siswa yang tidak hadir dalam pertemuan pertama, sehingga pretest hanya diberikan terhadap 31 siswa, sedangkan pada pertemuan terakhir terdapat 1 orang yang tidak hadir sehingga posttest hanya diberikan kepada 34 siswa. Pada kelas kontrol terdapat 2 orang siswa yang tidak mengikuti posttest, sehingga jumlah data pretest dan posttest yang dianalisis dalam penelitian ini adalah 64 siswa.

\section{Perolehan hasil Pretest dan Posttest}

Hasil perolehan nilai Pretest dan Posttest yang dikerjakan oleh siswa kelas eksperimen dan kelas kontrol ditentukan dengan rumus pada persamaan (1) berikut:

$$
X=\frac{\text { skor yang diperoleh }}{120} \times 100
$$

Dimana $X$ adalah nilai yang diperoleh siswa dan 120 (faktor penyebut dalam rumus) diperoleh dari jumlah total skor dari keseluruhan soal pretest dan posttest. Dimana jumlah total skor diperoleh dari nilai maksimal pada kriteria penskoran tes kemampuan pemecahan masalah (Polya) pada Tabel 1.

\section{Rata-rata Hasil Pretest dan Posttest}

Berdasarkan analisis nilai pretest dan posttest yang dikerjakan oleh siswa kelas eksperimen dan kelas kontrol diperoleh nilai rata-rata untuk masing-masing kelas seperti pada Tabel 4.

Tabel 4. Rata-rata Hasil Pretest dan Posttest

\begin{tabular}{lccccc}
\hline & N & Minimum & Maximum & Mean & Std. Deviation \\
\hline Pretest Eksperimen & 31 & 23 & 46 & 36,65 & 6,636 \\
\hline Posttest Eksperimen & 31 & 64 & 85 & 77,42 & 5,685 \\
\hline Pretest Kontrol & 33 & 28 & 45 & 36,36 & 5,207 \\
\hline Posttest Kontrol & 33 & 50 & 66 & 58,27 & 4,804 \\
\hline Valid N (listwise) & 31 & & & & \\
\hline
\end{tabular}

Berdasarkan analisis nilai pretest dan posttest yang dikerjakan oleh siswa kelas eksperimen dan kelas kontrol diperoleh nilai rata-rata untuk masing-masing kelas seperti pada Tabel 4, yaitu pada kelas eksperimen (kelas XI MIPA 4) dengan jumlah sampel 31 siswa, diperoleh nilai pretest terendah adalah 23 dan tertinggi 46 dari skor maksimal 100, sehingga rata-rata nilai pretest adalah 36,65 dengan standar deviasi 6,636. Sedangkan, nilai posttest terendah adalah 64 dan tertinggi 85 diperoleh ratarata nilai posttest adalah 77,42 dengan standar deviasi 5,685. Pada kelas kontrol (kelas XI MIPA 5) dengan jumlah sampel 33 siswa, diperoleh nilai pretest terendah adalah 28 dan tertinggi 45 sehingga rata-rata nilai pretest adalah 36,36 dengan standar deviasi 5,207 . Sedangkan, nilai posttest terendah adalah 50 dan tertinggi 66 diperoleh rata-rata nilai posttest adalah 58,27 dengan standar deviasi 4,804.

3. Analisis Indikator Kemampuan Pemecahan Masalah

Analisis skor per indikator kemampuan pemecahan masalah untuk mengetahui perbedaan skor 
Eksplorasi Kemampuan Pemecahan...

yang diperoleh pada tiap indikator saat pretest dan posttest kelas eksperimen dan kelas kontrol. Adapun rata-rata skor per indikator pada kelas eksperimen disajikan pada Tabel 5 berikut:

Tabel 5. Skor tiap Indikator Kelas Eksperimen

\begin{tabular}{lcc}
\hline \multirow{2}{*}{ Indikator } & \multicolumn{2}{c}{ Kelas Eksperimen } \\
\cline { 2 - 3 } & Pretest & Posttest \\
\hline Merumuskan Masalah & 1,8 & 2,6 \\
\hline Rencana Penyelesaian Masalah & 1,6 & 2,8 \\
\hline Penyelesaian Masalah & 0,9 & 2,4 \\
\hline Pengecekan Kembali & 0,2 & 1,4 \\
\hline
\end{tabular}

Berdasarkan Tabel 5, mengenai rata-rata perolehan skor tiap indikator kemampuan pemecahan masalah saat pretest dan posttest pada kelas eksperimen, diketahui bahwa untuk indikator memahami masalah masing-masing adalah 1,8 dan 2,6; untuk indikator merencanakan penyelesaian masalah adalah 1,6 dan 2,8; untuk indikator penyelesaian masalah adalah 0,9 dan 2,4; serta untuk indikator pengecekan kembali adalah 0,2 dan 1,4; dimana terjadi peningkatan disetiap indikator. Sedangkan, rata-rata skor per indikator pada kelas kontrol disajikan pada Tabel 6 berikut.

Tabel 6. Skor tiap Indikator Kelas Eksperimen

\begin{tabular}{lcc}
\hline \multirow{2}{*}{ Indikator } & \multicolumn{2}{c}{ Kelas Kontrol } \\
\cline { 2 - 3 } & Pretest & Posttest \\
\hline Merumuskan Masalah & 1,9 & 1,8 \\
\hline Rencana Penyelesaian Masalah & 1,6 & 1,8 \\
\hline Penyelesaian Masalah & 0,8 & 2,3 \\
\hline Pengecekan Kembali & 0,0 & 1,1 \\
\hline
\end{tabular}

Berdasarkan Tabel 6 rata-rata perolehan skor tiap indikator kemampuan pemecahan masalah saat pretest dan posttest pada kelas kontrol untuk indikator memahami masalah masing-masing adalah 1,9 dan 1,8 dimana hal ini menunjukkan terjadi penurunan skor saat posttest, untuk indikator merencanakan penyelesaian masalah masing-masing adalah 1,6 dan 1,8; untuk indikator penyelesaian masalah adalah 0,8 dan 2,3; serta untuk indikator pengecekan kembali adalah 0,0 dan 1,1.

Rata-rata skor tiap indikator kemampuan pemecahan masalah ini diperoleh dari sepuluh butir soal yang diberikan saat pretest dan posttest, dimana dalam menjawab soal ini terdapat empat langkah yang merupakan indikator kemampuan pemecahan masalah, sehingga pada setiap soal terdapat indikator yaitu memahami masalah (M), merencanakan penyelesaian masalah (R), penyelesaian masalah (P), dan pengecekan kembali $(\mathrm{K})$. Grafik rata-rata skor tiap indikator pretest dan posttest kelas eksperimen dapat dilihat pada Gambar 1 dan kelas kontrol.pada Gambar 2. 
Eksplorasi Kemampuan Pemecahan...

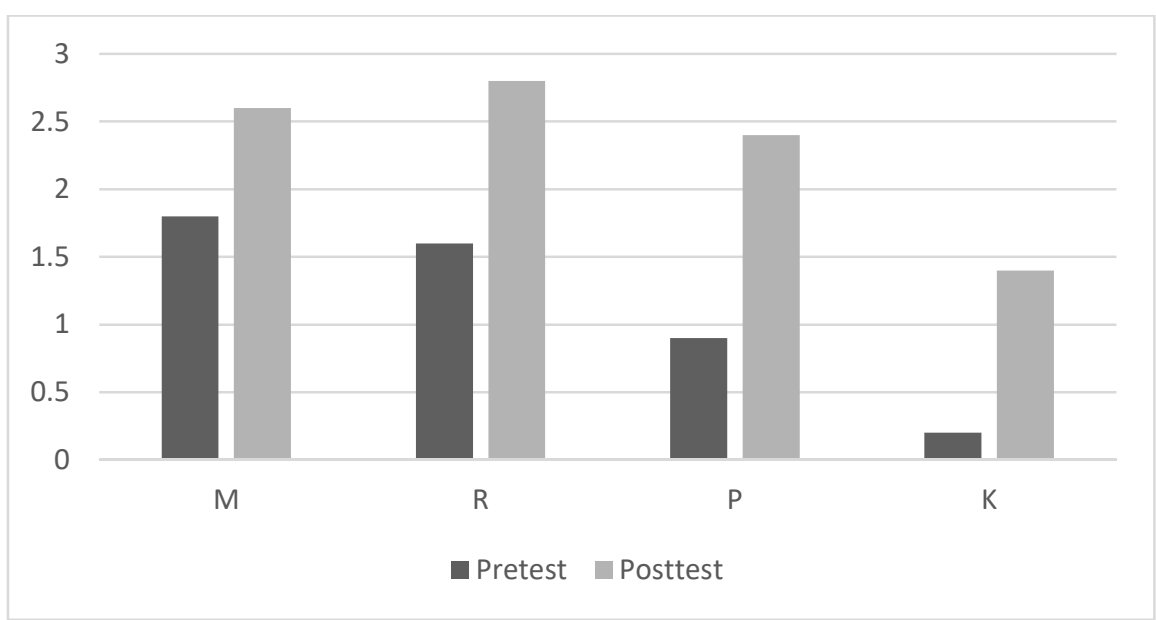

Gambar 1. Skor tiap Indikator pada Kelas Eksperimen

Adapun grafik rata-rata tiap indikator pretest dan posttest kelas kontrol adalah:

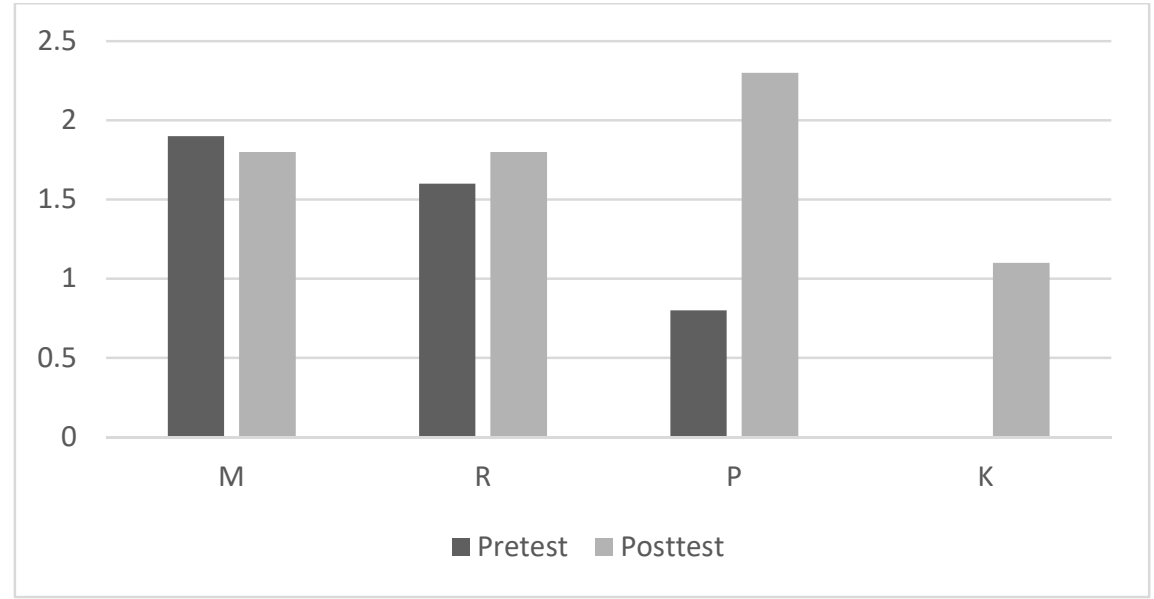

Gambar 2. Skor tiap Indikator pada Kelas Kontrol

4. Normalitas

Uji normalitas dilakukan dengan bantuan software SPSS 24 for Windows. Berikut ini adalah hasil output uji normalitas data hasil pretest dan posttest siswa kelas eksperimen dan kelas kontrol. Uji normalitas dengan menggunakan uji Kolmogorov-Smirnov diketahui dengan melihat bilangan yang terdapat dalam kolom signifikansi (Sig.). Hasil uji normalitas data kelas eksperimen dan kelas kontrol disajikan pada Tabel 7.

Tabel 7. Hasil Uji Normalitas Data Kelas Eksperimen dan Kelas Kontrol

\begin{tabular}{lccc}
\hline & \multicolumn{3}{c}{ Kolmogorov-Smirnova } \\
\cline { 2 - 4 } & Statistic & df & Sig. \\
\hline Pretest Eksperimen & 0,139 & 31 & 0,134 \\
\hline Posttest Eksperimen & 0,158 & 31 & 0,047 \\
\hline Pretest Kontrol & 0,229 & 33 & 0,000 \\
\hline Postest Kontrol & 0,200 & 33 & 0,002 \\
\hline
\end{tabular}


Eksplorasi Kemampuan Pemecahan...

Berdasarkan hasil uji normalitas pada Tabel 7 diketahui bahwa data dalam penelitian ini tidak terdistribusi normal. Hasil pengujian normalitas menunjukkan bahwa data pretest kelas eksperimen terdistribusi normal yaitu 0,134 yang mana lebih besar dari 0,05. Namun, data posttest kelas eksperimen, pretest dan posttest kelas kontrol tidak terdistribusi normal karena kurang dari 0,05. Sedangkan dalam uji normalitas dengan uji Kolmogorov-Smirnov apabila kedua data atau salah satu data tidak terdistribusi normal, maka disimpulkan bahwa data hasil penelitian tersebut tidak terdistribusi normal.

\section{Uji Homogenitas}

Pengujian homogenitas kelas eksperimen dan kelas kontrol dilakukan dengan menggunakan bantuan software SPSS 24 for Windows. Uji ini dilakukan untuk mengetahui data yang diperoleh dalam penelitian apakah homogen atau tidak. Hasil output uji homogenitas data pretest dan posttest kelas eksperimen dan kelas kontrol disajikan pada Tabel 8.

Tabel 8. Hasil Uji Homogenitas Data Kelas Eksperimen dan Kelas Kontrol

\begin{tabular}{lcccc}
\hline & $\begin{array}{c}\text { Levene } \\
\text { Statistic }\end{array}$ & df1 & df2 & Sig. \\
\hline Based on Mean & 0,627 & 1 & 65 & 0,431 \\
\hline Based on Median & 0,278 & 1 & 65 & 0,600 \\
\hline $\begin{array}{l}\text { Based on Median and } \\
\text { with adjusted df }\end{array}$ & 0,278 & 1 & 54,787 & 0,600 \\
\hline $\begin{array}{l}\text { Based on trimmed } \\
\text { mean }\end{array}$ & 0,552 & 1 & 65 & 0,460 \\
\hline
\end{tabular}

Hasil uji homogenitas pada Tabel 8 menunjukkan bahwa nilai signifikansi lebih besar dari 0,05, sehingga dapat disimpulkan bahwa data kelas eksperimen dan kelas kontrol adalah homogen.

\section{Uji Mann-Whitney}

Berdasarkan pemaparan hasil uji normalitas dan homogenitas diketahui bahwa data hasil penelitian tidak terdistribusi normal dan data homogen, hal ini tidak memenuhi syarat untuk dilakukannya uji hipotesis dengan uji $\mathrm{t}$, maka uji hipotesis yang digunakan adalah uji non parametrik yaitu uji MannWhitney. Hasil uji Mann-Whitney disajikan pada Tabel 9.

Tabel 9. Hasil Uji Mann-Whitney

\begin{tabular}{lc}
\hline \multicolumn{2}{c}{ Test Statistics $^{\text {a }}$} \\
\hline Mann-Whitney U & 4,500 \\
\hline Wilcoxon W & 565,500 \\
\hline Z & $-6,991$ \\
\hline Asymp. Sig. (2-tailed) & 0,000 \\
\hline
\end{tabular}

Dalam uji hipotesis menggunakan uji Mann-Whitney pengambilan keputusan dilihat dari nilai signifikansi (Sig.) yang terdapat dalam baris Asymp.Sig. (2-tailed). Apabila nilai signifikansi (Sig.) lebih kecil dari 0,05 maka Ho ditolak dan Ha diterima. Sebaliknya, jika signifikansi lebih besar dari 0,05 maka Ho diterima dan Ha ditolak. Berdasarkan tabel 9. pada baris Asymp. Sig. (2-tailed) diperoleh informasi bahwa p-value (Sig.) data yang telah diuji adalah 0,000 di mana nilai tersebut lebih kecil dari 0,05, sehingga diketahui bahwa hipotesis awal $(\mathrm{Ho})$ ditolak dan hipotesis alternatif $(\mathrm{Ha})$ diterima. Ha yang dimaksudkan dalam uji ini adalah ada perbedaan yang signifikan antara kemampuan pemecahan masalah siswa kelas eksperimen dengan model discovery learning dan kelas kontrol dengan model pembelajaran konvensional.

7. Analisis N-Gain

Uji N-Gain memberikan gambaran umum peningkatan hasil pembelajaran, yaitu peningkatan nilai 
Eksplorasi Kemampuan Pemecahan...

kemampuan pemecahan masalah siswa antara kelas eksperimen yang telah diterapkan model discovery learning dengan kelas kontrol. Hasil uji N-Gain disajikan pada Tabel 10.

Tabel 10. Hasil Uji N-Gain

\begin{tabular}{lcl}
\hline $\mathbf{N}$-Gain & Rata-rata & Kriteria \\
\hline Kelas Eksperimen & 0,6 & Sedang \\
\hline Kelas Kontrol & 0,3 & Sedang \\
\hline
\end{tabular}

Berdasarkan hasil uji $\mathrm{N}$-Gain pada Tabel 10, menunjukkan bahwa nilai rata-rata $\mathrm{N}$-Gain untuk kelas eksperimen adalah 0,6 yang termasuk dalam kategori sedang, dengan nilai $\mathrm{N}$-Gain minimal 0,4 dan maksimal 0,8 . Sementara rata-rata nilai $\mathrm{N}$-Gain untuk kelas kontrol adalah 0,3 yang juga termasuk kategori sedang, dengan nilai $\mathrm{N}$-Gain minimal 0,2 dan maksimal 0,5. Dari data tersebut, dapat disimpulkan bahwa terjadi peningkatan antara kedua kelas yang termasuk dalam kategori sedang, namun jika dilihat dari besarnya rata-rata nilai $\mathrm{N}$-Gain, maka peningkatan kemampuan pemecahan masalah pada kelas eksperimen lebih besar daripada kelas kontrol, dimana rata-rata $\mathrm{N}$-Gain kelas eksperimen adalah 0,6 dan kelas kontrol 0,3.

\section{PEMBAHASAN}

Proses pembelajaran yang dilakukan di kelas disesuaikan dengan RPP yang telah disusun. Seluruh pertemuan dilaksanakan menggunakan model discovery learning yang disertai penggunaan lembar kerja peserta didik (LKPD) dan percobaan. Langkah-langkah dalam LKPD yang berbasis model discovery learning telah dirancang sesuai dengan indikator pemecahan masalah menurut Polya. LKPD ini sebagai penunjang terlaksananya pembelajaran yang sesuai dengan indikator pemecahan masalah.

Indikator pemecahan masalah yang digunakan dalam penelitian ini merupakan empat tahap yang dilakukan agar siswa lebih terarah dalam menyelesaikan masalah, yaitu understanding the problem, devising plan, carrying out the plan, and looking back yang diartikan sebagai memahami masalah, menyusun rencana pemecahan masalah, melaksanakan rencana, dan memeriksa kembali hasil yang diperoleh. Tahapan-tahapan tersebut yang digunakan untuk menilai bagaimana kemampuan pemecahan masalah siswa dalam menjawab soal. Setiap soal pretest dan posttest yang dijawab oleh siswa mengandung indikator pemecahan masalah yang dinilai menggunakan kriteria penskoran pada Tabel 2, dimana skor maksimal tiap indikator adalah 3 dan minimal adalah 0.

\section{Kemampuan Pemecahan Masalah}

Berdasarkan pada kriteria penskoran pada Tabel 2, maka perolehan rata-rata skor tiap indikator ini menunjukkan bahwa pada saat pretest kelas eksperimen, siswa kurang tepat dalam memahami masalah, yaitu saat siswa menuliskan informasi yang terdapat dalam soal. Namun, saat posttest lebih banyak siswa yang dapat memahami masalah dengan menuliskan informasi yang terdapat pada soal, sebagian atau lengkap dan dengan tepat. Pada kelas kontrol, lebih banyak siswa yang dapat memahami masalah dengan menuliskan informasi yang terdapat pada soal saat pretest daripada saat posttest, hal ini dapat terjadi karena pemberian soal yang sama saat pretest dan posttest sehingga beberapa siswa tidak lagi menuliskan informasi yang terdapat pada soal tetapi langsung menjawabnya. Untuk indikator merencanakan penyelesaian masalah pada kelas eksperimen dan kelas kontrol dimana saat pretest hanya sebagian siswa yang dapat menuliskan rencana penyelesaian masalah dengan benar, saat posttest kelas ekperimen lebih banyak siswa yang dapat merumuskan masalah dengan tepat sedangkan pada posttest kelas kontrol siswa langsung menuliskan penyelesaian masalah tanpa membuat dan menuliskan perencanaan penyelesaian masalah dengan tepat. Untuk indikator penyelesaian masalah saat pretest dan posttest kedua kelas dapat menyelesaikan masalah dengan tepat, namun beberapa siswa menjawab dengan tepat, tetapi kurang lengkap. Sedangkan, untuk indikator pengecekan kembali pada pretest dan posttest hanya beberapa siswa yang melakukan pengecekan kembali dengan tepat baik itu pada kelas eksperimen maupun kelas kontrol. 
Eksplorasi Kemampuan Pemecahan...

\section{Analisis Nilai pretest dan posttest}

Data yang diperoleh pada penelitian ini adalah data nilai pretest dan posttest. Analisis data dilakukan dengan melakukan uji normalitas, uji homogenitas, uji hipotesis, dan uji $\mathrm{N}$-Gain. Uji normalitas dan uji homogenitas dilakukan terlebih dahulu untuk menentukan uji hipotesis yang akan digunakan. Jika memenuhi syarat (data berdistribusi normal dan homogen) maka uji hipotesis yang akan digunakan adalah uji t. Namun, jika tidak memenuhi syarat maka uji hipotesis yang akan digunakan adalah uji hipotesis nonparametrik yaitu uji Mann-Whitney.

Berdasarkan hasil uji normalitas pada Tabel 7 , diketahui bahwa data dalam penelitian ini tidak terdistribusi normal. Hasil uji homogenitas pada Tabel 8 menunjukkan bahwa nilai signifikansi lebih besar dari 0,05 , sehingga dapat disimpulkan bahwa data kelas eksperimen dan kelas kontrol adalah homogen.

Berdasarkan pemaparan hasil uji normalitas dan homogenitas diketahui bahwa data hasil penelitian tidak terdistribusi normal dan data homogen, hal ini tidak memenuhi syarat untuk dilakukannya uji hipotesis dengan uji t, maka uji hipotesis yang digunakan adalah uji non parametrik yaitu uji MannWhitney.

Hasil analisis uji Mann-Whitney pada Tabel 9 menunjukkan bahwa model discovery learning berpengaruh terhadap kemampuan pemecahan masalah siswa. Pernyataan tersebut berdasarkan pada hasil uji hipotesis terhadap kemampuan pemecahan masalah siswa yang menunjukkan bahwa hipotesis awal $\left(\mathrm{H}_{\mathrm{o}}\right)$ ditolak dan hipotesis alternatif $\left(\mathrm{H}_{\mathrm{a}}\right)$ diterima. Ha yang dimaksudkan adalah adanya perbedaan yang signifikan antara kemampuan pemecahan masalah siswa kelas eksperimen dengan model discovery learning dan kelas kontrol dengan model pembelajaran konvensional. Hal ini berarti bahwa nilai rata-rata kemampuan pemecahan masalah siswa kelas kontrol dan kelas eksperimen berbeda dimana nilai rata-rata kemampuan pemecahan masalah kelas eksperimen lebih baik daripada kelas kontrol. Hal tersebut juga disebabkan karena penerapan model discovery learning yang menekankan pada pengalaman belajar secara langsung dan berpusat pada siswa melalui kegiatan penyelidikan, menemukan konsep dan kemudian menerapkan konsep dalam kehidupan sehari-hari. Proses dalam penerapan model ini merepresentasikan sebuah siklus pembelajaran, siswa akan dilatih untuk memecahkan permasalahan. Hal ini juga relevan dengan penelitian yang dilakukan oleh Wartono (2019) yang menunjukkan bahwa hasil kemampuan pemecahan masalah siswa kelas eksperimen dengan pembelajaran inquiry-discovery lebih tinggi dibandingkan dengan kelas kontrol dengan pembelajaran konvensional. Hal ini disebabkan pembelajaran inquiry-discovery merupakan pembelajaran yang melibatkan siswa dalam melakukan penyelidikan untuk menemukan konsep berdasarkan fnomena fisika. Dengan pembelarajan discovery learning siswa terbiasa menemukan sendiri konsep pengetahuannya sehingga dengan pembelajaran yang demikian dapat melatih kemampuan pemecahan masalah siswa.

Pada penelitian ini dilakukan pula uji N-Gain yang memberikan gambaran umum peningkatan hasil pembelajaran, yaitu peningkatan nilai kemampuan pemecahan masalah siswa antara kelas eksperimen yang telah diterapkan model discovery learning dengan kelas kontrol. Uji $N$-Gain diperoleh dari nilai pretest dan posttest kedua kelas. Uji ini bertujuan untuk mengetahui peningkatan hasil pembelajaran antara kelas eksperimen dan kelas kontrol. Hasil uji $N$-Gain dapat dilihat pada Tabel 10 yang menunjukkan bahwa kemampuan pemecahan masalah pada kelas eksperimen lebih besar daripada kelas kontrol, dimana rata-rata $\mathrm{N}$-Gain kelas eksperimen adalah 0,6 dan kelas kontrol 0,3.

\section{Pembelajaran dengan Model Discovery Learning}

Dalam proses pembelajaran yang dilakukan, peneliti terlebih dahulu menjelaskan rancangan pembelajaran yang akan dilaksanakan, menjelaskan isi LKPD dan perkenalan alat-alat percobaan. Kemudian siswa diarahkan untuk merumuskan masalah berdasarkan pengantar pada LKPD yang dimiliki siswa, lalu peneliti mengarahkan siswa untuk merencanakan langkah-langkah percobaan, mencari informasi terkait materi pembelajaran di buku, kemudian melakukan percobaan. Setelah siswa 
Eksplorasi Kemampuan Pemecahan...

menyelesaikan percobaan dan menjawab pertanyaan pada LKPD, perwakilan masing-masing kelompok akan mempresentasikan hasil percobaannya. Peneliti bersama siswa lain menanggapi dan mengevaluasi hasil presentasi siswa. Setelah seluruh kelompok mempresentasikan hasil percobaannya, peneliti menjelaskan kembali materi yang telah dipelajari dan diperoleh saat percobaan sebagai penguatan terhadap materi pembelajaran.

Pada pertemuan pertama pembelajaran, terdapat 31 siswa yang hadir dan 4 yang tidak hadir. Sehingga siswa pada kelas eksperimen yang mengikuti pretest adalah 31 siswa. Pretest dilakukan selama 45 menit pada pertemuan pertama, kemudian dilanjutkan dengan percobaan tentang tekanan hidrostatis. Saat percobaan dilakukan terdapat beberapa siswa yang kesulitan saat merencanakan langkah-langkah percobaan yaitu dalam menentukan letak atau posisi corong pada gelas kimia, selain itu ada juga yang sulit mengamati perubahan yang terjadi pada pipa $U$ karena balon pada corong tidak terpasang dengan baik. Sehingga, peneliti mengarahkan dan membimbing siswa untuk mengamati kembali gambar pada LKPD dan menjelaskan mengenai konsep fisika dalam percobaan. Setelah percobaan selesai, perwakilan kelompok akan mempresentasikan hasil percobaannya. Namun, karena keterbatasan waktu, hanya 2 kelompok yang melakukan presentasi dan peneliti tidak menjelaskan materi lagi. Materi pembelajaran mengenai tekanan hidrostatis dilanjutkan pada pertemuan kedua.

Pada pertemuan kedua, sebelum melaksanakan percobaan tentang Hukum Pascal, peneliti terlebih dahulu menjelaskan kembali materi pada pertemuan sebelumnya, sebagai penguatan atas pembelajaran yang telah dilakukan. Saat percobaan berlangsung, terdapat satu kelompok yang tidak dapat melaksanakan percobaan karena salah satu alat rusak (suntikan), sehingga kelompok tersebut harus menunggu alat dari kelompok lain. Pertemuan ketiga tentang Hukum Archimedes, kendala yang dialami saat menyelesaikan masalah yaitu setelah percobaan dan diperoleh data, terdapat beberapa siswa yang kebingungan menentukan berat air yang tumpah karena pada percobaan tidak menggunakan timbangan untuk mengukur berat air tersebut.

Pada pertemuan keempat tentang tegangan permukaan, siswa mengalami kesulitan dalam memahami masalah, membedakan antara peristiwa tegangan permukaan dan Hukum Archimedes. Pembelajaran pada kelas eksperimen dilakukan dengan percobaan dan penjelasan materi oleh peneliti diakhir pembelajaran. Pada pertemuan kelima, peneliti menjelaskan dan membahas beberapa contoh soal terkait materi yang telah dipelajari, kemudian dilakukan posttest sebagai tes akhir kemampuan pemecahan masalah siswa.

Berdasarkan pemaparan proses pembelajaran di atas, diperoleh informasi bahwa pada pembelajaran dengan model discovery learning waktu banyak dihabiskan pada langkah pengumpulan data dalam hal ini percobaan, sehingga waktu untuk pengolahan data dan pembuktian menjadi sangat singkat. Hal ini juga dikemukanan oleh Wahyu Tri Winarti (2021) bahwa model Model discovery learning berbasis edutainment dapat menjadikan peserta didik aktif dalam kegiatan belajar dan menyenangkan. Namun, memerlukan waktu yang cukup lama dalam pembelajarannya dan kurang efektif digunakan dalam kelas besar.

Berdasarkan hasil pretest dan posttest dari kedua kelas tersebut yang kemudian dianalisis ternyata membuktikan bahwa terdapat pengaruh model discovery learning terhadap kemampuan pemecahan masalah siswa kelas eksperimen dan hasil tersebut menjawab rumusan masalah dalam penelitian ini yang telah dijabarkan sebelumnya. Hal ini relevan dengan penelitian yang dilakukan oleh Elsa Handayani (2019) yang menyatakan bahwa terhadap kemampuan pemecahan masalah siswa yang menggunakan model discovery learning berbantuan media PhET dengan siswa yang menggunakan pembelajaran konvensional.

Beberapa kelebihan dari model pembelajaran discovery learning yang ditemukan dalam penelitian ini adalah mampu meningkatkan kemampuan siswa untuk memecahkan masalah, meningkatkan motivasi siswa terlibat dalam merumuskan masalah, melakukan percobaan serta diskusi antar kelompok maupun mempresentasikan hasil, serta melatih kemandirian siswa dalam mengerjakan soal.

Berdasarkan penelitian yang telah dilakukan dapat disimpulkan bahwa penerapan model discovery learning dapat meningkatkan kemampuan pemecahan masalah siswa SMA pada materi fluida statis. 
Eksplorasi Kemampuan Pemecahan...

Hal ini relevan dengan penelitian yang telah dilakukan Nurjamilah (2017) dari Universitas Mulawarman yang menyatakan bahwa terdapat perbedaan yang signifikan antara nilai rata-rata posttest dan pretest setelah diterapkan model discovery learning, dan pada penelitian Nurhasanah (2018) dari Universitas Negeri Majalengka yang menyatakan bahwa penggunaan model discovery learning dapat meningkatkan kemampuan pemecahan masalah matematis siswa dengan baik.

\section{PENUTUP}

Berdasarkan data hasil penelitian yang telah dilakukan di SMA Negeri 3 Samarinda, diperoleh hasil uji tes non parametrik menggunakan uji Mann-Whitney yang menyatakan bahwa nilai signifikansi yang didapat adalah 0,000 atau kurang dari 0,05 sehingga $\mathrm{H}_{\circ}$ ditolak dan $\mathrm{H}_{a}$ diterima, sehingga dapat disimpulkan bahwa terdapat pengaruh model pembelajaran discovery learning terhadap kemampuan pemecahan masalah siswa kelas XI SMA pada materi fluida statis.

Adapun saran yang dapat diberikan berdasarkan penelitian yang telah dilakukan yaitu pembelajaran dengan model discovery learning pada langkah pengumpulan dan pengolahan data memerlukan waktu yang cukup banyak sehingga guru harus mampu mengatur waktu pada awal kegiatan agar dapat menyelesaikan langkah-langkah selanjutnya. Selain itu, pada tahap perumusan masalah guru harus selalu membimbing dan mendampingi siswa agar perumusan siswa tidak keluar dari materi pembelajaran yang akan dibahas. Keterbatasan dari penelitian ini adalah peninjauan pengaruh model discovery learning berdasarkan masing-masing indikator pemecahan masalah yang kurang spesifik. Oleh sebab itu, pada penelitian berikutnya diharapkan agar peneliti bisa menggali informasi lebih lanjut mengenai pengaruh model tersebut pada masing-masing indikator kemampuan pemecahan masalah secara lebih kompleks.

\section{DAFTAR PUSTAKA}

Bekti, Tri. (2014). Profil Pemecahan Masalah Berbentuk Open-Ended Berdasarkan Tahapan Polya pada Siswa SMP Negeri 5 Salatiga dalam Materi Lingkaran. Skripsi. Salatiga: Universitas Kristen Satya Wacana.

Dede E. H, dkk. (2018). Penggunaan Model Pembelajaran Discovery Learning untuk Meningkatkan Kemampuan Pemecahan Masalah pada Siswa SMP. Jurnal Didactical Mathematic. 1(1), 21-32.

Destianingsih, E., dkk. (2015). Pengaruh Model Problem Based Learning terhadap Kemampuan Pemecahan Masalah Siswa pada Pembelajaran Fisika Kelas XI di SMA Negeri Tanjung Lubuk. Jurnal Fisika Program Studi Pendidikan Fisika Universitas Sriwijaya

Dwi, Sembada. (2012). Perana Kreativitas Siswa terhadap Kemampuan Pemecahan Masalah dalam Pembelajaran Kontekstual. Jurnal Pendidikan Fisika dan Aplikasi (JPFA), 2(2), 37-47.

Fadhlin, Azizah. (2012). Pengaruh Penggunaan Model Pembelajaran Problem Based Instruction (PBI) Terhadap Kemampuan Pemecahan Masalah Matematika Siswa Madrasah Tarbiyah Islamiah Batu Belah Kecamatan Kampar. Skripsi. Universitas Islam Negeri Sultan Syarif Kasim Riau.

Fraenkel, Jack. R., dan Norman E. Wallen. (2012). How to Design and Evaluate Reseach in Education. McGraw-Hill Higher Education.

Hake, R. R. (1999). Analyzing Change/Gain Scores. Woodland Hills: Indiana University.

Handayani, Elsa dan Simamora, Pintor. (2019). Pengaruh Model Discovery Learning Berbantuan Media PhET terhadap Kemampuan Pemecahan Masalah Tingkat SMA pada Materi Pokok Fluida Dinamis. Jurnal Inovasi Pembalajaran Fisika. 1(1), 21-27.

Herdiana, Yunita, dkk. (2017). Effectiveness of Discovery Learning Model on Mathematic Problem 
Eksplorasi Kemampuan Pemecahan...

Solving. AIP Conference Proceedings

Kemendikbud. (2019). Hasil PISA Indonesia 2018. Diakses pada 2 Maret 2020 dari https://www.kemdikbud.go.id/main/blog/2019/12/hasil-pisa-indonesia-2018-akses-makin-meluassaatnya-tingkatkan-kualitas.

Kurniawati. (2011). Model-model Pembelajaran Didalam Kelas. Jakarta: PT. Tiga Serangkai Pustaka Mandiri.

Masjaya. (2018). Pentingnya Kemampuan Literasi Matematika untuk Menumbuhkan Kemampuan Konensi Matematika dalam Meningkatkan SDM. PRISMA Proseding Seminar Nasional Matematika.Vol. 1 No. 568, $568-574$

Nurjamilah, dkk. (2017). Penggunaan Instrumen Ordered Multiple Choice (OMC) untuk Menilai Pemahaman Konsep Usaha dan Energi dengan Model Pembelajaran Discovery Learning. Berkala IImiah Pendidikan Fisika. 5(3), 11-12.

Selcuk, G.S. Calistan, S. dan Erol, M. (2008). The Effects of Problem solving Instruction on Physics Achievement, Problem Solving Performance and Strategy Use. Latin American Journal of Physics Education, 2(3), 153-166

Slavin, Nur. (1997). Belajar Pembelajaran Menggunanakan Model Discovery Learnng. Bandung: PT. Rosdakarya.

Sulistyowati, Nastiti. (2012). Efektivitas Model Pembelajaran Guided Discovery Learning Terhadap Kemampuan Pemecahan Masalah Kimia. Chemistry in Education. 2(1), 45-55.

Suprijono, Anas. (2012). Pengantar Model Pembelajaran Discovery Learning. Jakarta: Raja Grafindo Persada.

Taufik, S. dan Abdulhak T. (2010). Desain Model Pembelajaran untuk Meningkatkan Kemampuan Pemecahan Masalah dalam Pembelajaran IPA (Fisika) Sekolah Menengah Pertama di Kota Bandung.

Wartono, dkk. (2019). Peningkatan Kemampuan Pemecahan Masalah dengan Model Pembelajaran Inquiry-Discovery. EDUSAINS. 11(2), 242-248.

Winarti, W. T., dkk. (2021). Pembelajaran Fisika Menggunakan Model Discovery Learning Berbasis Edutainment. Jurnal IImiah Pendidikan Fisika. 5(1), 54-54. 